\title{
Arbuscular mycorrhizal fungal communities in an iron mining area and its surroundings: Inoculum potential, density, and diversity of spores related to soil properties
}

\section{Comunidades de fungos micorrízicos arbusculares em área de mineração e seu entorno: Potencial de inóculo, densidade e diversidade de esporos relacionados a atributos do solo}

\author{
Anita Fernanda dos Santos Teixeira ${ }^{1}$, Karl Kemmelmeier ${ }^{1}$, Matheus Nicoletti Marascalchi ${ }^{2}$, \\ Sidney Luiz Stürmer ${ }^{2}$, Marco Aurélio Carbone Carneiro ${ }^{1}$, Fatima Maria de Souza Moreira ${ }^{1 *}$
}

\author{
'Universidade Federal de Lavras/UFLA, Departamento de Ciência do Solo/DCS, Lavras, MG, Brasil \\ ¿Universidade Regional de Blumenau/FURB, Departamento de Ciências Naturais, Blumenau, SC, Brasil \\ ${ }^{*}$ Corresponding author: fmoreira@dcs.ufla.br \\ Received in May 20, 2016 and approved in July 25, 2017
}

\begin{abstract}
Arbuscular mycorrhizal fungi (AMF) interact symbiotically with most plant species, facilitating revegetation of areas under rehabilitation. The aim of this study was to evaluate the inoculum potential, density, and diversity of AMF spores in five environments, as well as the relation of species with soil properties. Soil samples were collected in five environments in a mining area and its surroundings in the Quadrilátero Ferrífero, Minas Gerais (Brazil): tailings piles in rehabilitation with grass, canga, Cerrado, native forest, and eucalyptus plantation; these samples were subjected to chemical and physical analyses. Spores were directly extracted from field samples and from trap cultures (TCs) established in two locations in the Southeast and South regions of Brazil for taxonomic identification of the species. Species richness, the Shannon diversity index $\left(\mathrm{H}^{\prime}\right)$, and equitability were determined. Principal component analysis (PCA) was used to identify soil properties that most influenced AMF occurrence. Spore density showed no significant difference among the environments. A total of 59 AMF species were found. This is the first report of the occurrence of Acaulospora nivalis and Acaulospora alpina in Brazil. Higher $\mathrm{H}^{\prime}$ and species richness in the field were found in tailings piles and lower in canga. Canga showed higher inoculum potential. The development of TCs in two locations allowed a wider diversity of AMF species to be captured. Environments of the Quadrilatero Ferrifero are hotspots of AMF diversity, and the soil pH and exchangeable $\mathrm{S}$ and $\mathrm{P}$ contents are the properties that best explain the distribution of AMF species.
\end{abstract}

Index terms: Tailings piles; Glomeromycota; ironstone; rehabilitation.

\section{RESUMO}

Fungos micorrízicos arbusculares (AMF) interagem simbioticamente com a maioria das espécies de plantas, facilitando a revegetação de áreas sob reabilitação. O objetivo deste trabalho foi de avaliar o potencial de inóculo, densidade e diversidade de esporos de AMF em cinco ambientes, e a relação das espécies com atributos do solo. Amostras de solo foram coletadas em cinco ambientes em área de mineração e seu entorno no Quadrilátero Ferrífero, Minas Gerais (Brasil): pilha de rejeitos em reabilitação com capim, canga, Cerrado, mata nativa e plantação de eucalipto, e submetidas a análises química e física. A extração de esporos direto de amostras de campo e de culturas armadilha (TCS), estabelecidas em dois locais nas regiões Sul e Sudeste do Brasil, foi feita para identificação taxonômica das espécies. Foram determinados riqueza de espécies, índice de diversidade de Shannon ( $\left.\mathrm{H}^{\prime}\right)$ e equitabilidade. Análise de componentes principais (PCA) foi utilizada para identificar atributos do solo que mais influenciaram a ocorrência de AMF. A densidade de esporos não diferiu significativamente entre os ambientes. Um total de 59 espécies de AMF foram encontradas, destacando-se o primeiro relato de ocorrência de Acaulospora nivalis e Acaulospora alpina no Brasil. Maiores H' e riqueza de espécies no campo foram encontradas em pilhas de rejeitos e menores em canga, embora canga tenha apresentado maior potencial de inóculo. A condução de TCs em dois locais proporcionou captura de maior diversidade de espécies de AMF. Ambientes do Quadrilátero Ferrífero são hotspots de diversidade de AMF e o pH do solo e teores trocáveis de $\mathrm{S}$ e $\mathrm{P}$ são os atributos que melhor explicam a distribuição das espécies de AMF.

Termos para indexação: Pilhas de rejeitos; Glomeromycota; canga; reabilitação.

\section{INTRODUCTION}

Brazil is the third largest producer of iron ore worldwide, and approximately $70 \%$ of this ore is extracted in the state of Minas Gerais (Brasil, 2016), which has areas with high concentrations of iron $(\mathrm{Fe})$. One of these areas in the central part of Minas Gerais is known as the Quadrilátero Ferrifero, which is of great historical-cultural and economic importance due to iron ore extraction (Carvalho Filho; Curi; Shinzato, 2010). However, although the extraction of $\mathrm{Fe}$ is economically important, iron mining 
brings about changes in the landscape, with impacts on plant cover, on soil biodiversity, and, consequently, on the biogeochemical cycles of the elements (Siqueira et al., 2007; Xing et al., 2015) since the process of opening mining pits involves removing soil over the ore (which is sterile) and depositing it in other locations, forming piles.

Surrounding these mining areas in the Quadrilátero Ferrífero, there are diverse floristic domains with vestiges of secondary forest that are characteristic of the Atlantic Forest and Cerrado (Brazilian tropical savanna) biomes, both considered as worldwide hotspots of diversity (Hopper; Silveira; Fiedler, 2016). The Cerrado, particularly, is recognized as one of the most ecologically important savannas of the world due to its high diversity of habitats, home to an estimated 11,627 species of native plants (Brasil, 2015). Among the habitats of the Cerrado, the canga is prominent through its association with ferruginous outcroppings and underground hardpans, its scarcity of soil volume, and the intense daily variation in temperature, which hinders establishment of plants and makes it one of the most endangered ecosystems of Brazil (Matias et al., 2009; Skirycz et al., 2014).

The stability and resilience of the environment depends on the biodiversity that ensures ecological services (Mori; Furukawa; Sasaki, 2013). Revegetation can provide the biodiversity necessary for recovery of areas impacted by mining. In this context, arbuscular mycorrhizal fungi (AMF Glomeromycota phylum) represent important components of the soil biota that promote diverse services in the ecosystem (Pellegrino; Bedini, 2014), such as better plant nutrition and growth (Thirkell; Cameron; Hodge, 2016), soil aggregation (Leifheit; Verbruggen; Rillig, 2015) and an increase in plant tolerance to biotic stresses (e.g., pathogens) (Liang et al., 2015) and abiotic stresses (e.g., potentially toxic elements in the soil) (Cabral et al., 2015), and assume an important role in the rehabilitation process of areas affected by mining.

However, since AMF are necessarily biotrophic, they are also affected by removal of original vegetation and interventions in the soil of an area. Removal of the surface layer of the soil for ore extraction and creation of tailings piles has a negative influence on soil structure and can reduce its mycorrhizal inoculum potential since this breaks down the network of infective hyphae in the soil (Siqueira et al., 2007; Soares; Carneiro, 2010).

Among the propagules of AMF able to begin mycorrhizal colonization, such as hyphae in the soil and colonized roots, spores are the most resistant fungal structures and hold the important morphological characteristics for determination of the species (Pagano et al., 2016). Analysis of the diversity of AMF species and of inoculum potential in areas affected by mining and their surroundings represents one step in identifying the fungal species with potential for use in revegetation processes for the purpose of recovering areas affected by mining. However, few studies have evaluated the diversity of AMF in Fe mining and deposition areas.

Rehabilitation of mining areas is normally performed through planting of grasses, which assist in stabilization of the tailings piles. In dealing with soil with human intervention, studies comparing the soil biota of these areas to less altered surrounding areas can indicate the effectiveness of the recovery process adopted. Thus, the aim of this study was (i) to evaluate the potential of mycorrhizal inoculum, density, and diversity of AMF spores in an area in rehabilitation after $\mathrm{Fe}$ mining and its surroundings, consisting of five environments: tailings piles in rehabilitation, canga, Cerrado, forest, and planted eucalyptus forest; and (ii) to identify the chemical and physical soil properties that most explain the occurrence of AMF species in those environments.

\section{MATERIAL AND METHODS}

\section{Study area}

The study was carried out at the Córrego do Meio mine $\left(19^{\circ} 51^{\prime} 41.23^{\prime \prime} \mathrm{S}, 43^{\circ} 48^{\prime} 11.13^{\prime} \mathrm{W}\right)$, totally deactivated in 2006, in the municipality of Sabará, MG, Brazil, in five different environments: tailings piles in rehabilitation (TP), canga (CN), Cerrado (CE), forest (FT), and planted eucalyptus (PE) (Table 1). The five environments evaluated are located within the morphostructural unit of the Quadrilátero Ferrifero. Climate in the region is highland tropical, Cwa according to Köppen, with warm and humid summers and cold and dry winters. Mean annual rainfall is $1700 \mathrm{~mm}$, with a short dry period in the winter, and mean annual temperature is $22^{\circ} \mathrm{C}$.

In each sampling environment, four soil samples were collected in September 2013. Each sample was composed of 12 subsamples collected at the depth of zero to $20 \mathrm{~cm}$, with four of them taken at three meters and eight taken at six meters from the georeferenced center point, according to the sampling arrangement proposed by Huising et al. (2008). Samples were subjected to analysis of chemical and physical properties (personal information from Patrícia de Freitas Costa).

Compound soil samples that were used for microbiological analyses were homogenized and arranged for transport to the Soil Biology, Microbiology, and Biological Processes Laboratory of the Universidade Federal de Lavras (UFLA), where they were placed in cold storage at $4{ }^{\circ} \mathrm{C}$ until evaluation. 
Table 1: Description and range of elevation of the environments studied at the Córrego do Meio mine, state of Minas Gerais, Brazil.

\begin{tabular}{|c|c|c|c|}
\hline Environment & Description & $\begin{array}{c}\text { Range of } \\
\text { Elevation }(\mathrm{m})\end{array}$ & Soil Class \\
\hline Tailings piles & $\begin{array}{l}\text { Area in process of environmental recovery after } \\
\text { iron mining, replanted with molasses grass } \\
\text { (Melinis minutiflora P. Beauv.). }\end{array}$ & 1041 to 1060 & Anthrosol \\
\hline Canga & $\begin{array}{l}\text { Rocky environment well preserved over rocky } \\
\text { outcroppings. }\end{array}$ & 1196 to 1201 & Litholic Neosol \\
\hline Cerrado & $\begin{array}{l}\text { Typical Cerrado vegetation with a low degree of } \\
\text { anthropic influence. }\end{array}$ & 992 to 1006 & Haplic Cambisol \\
\hline Planted eucalyptus forest & $\begin{array}{l}\text { Reforested area planted predominantly with } \\
\text { Eucalyptus spp. }\end{array}$ & 926 to 971 & Haplic Cambiso \\
\hline Forest & $\begin{array}{l}\text { Secondary vegetation at different stages of } \\
\text { natural regeneration, originally belonging to the } \\
\text { Atlantic Forest biome. }\end{array}$ & 880 to 966 & Haplic Cambisol \\
\hline
\end{tabular}

\section{Field spore extraction and identification}

The AMF spores were extracted from $100 \mathrm{~mL}$ of each soil sample following the wet sieving and decanting technique (Gerdemann; Nicolson, 1963), combined with the water and $50 \%$ sucrose centrifuge technique (Jenkins, 1964). Apparently viable spores were observed in a stereo microscope and separated into morphotypes according to color, size, and shape and mounted on slides with polyvinyl lactoglycerol (PVLG) and Melzer reagent for observation on a microscope and taxonomic identification through spore morphology. AMF species were identified considering the size, shape, color, presence of subcellular structures of the spores, and comparison with the descriptions contained in the International Collection of Arbuscular and Vesicular-Arbuscular Mycorrhizal Fungi (INVAM, 2016) and in Błaszkowski (2012).

\section{Trap cultures}

Trap cultures (TCs) were set up in the Soil Science Department of the Universidade Federal de Lavras (UFLA) in Lavras, Minas Gerais, in the Southeast region of Brazil, and in the Natural Sciences Department of the Universidade Regional de Blumenau (FURB) in Blumenau, Santa Catarina, in the South region of Brazil. The climate of Lavras, according to the Köppen climate classification, is Cwa, rainy temperate (mesothermal), with a dry winter and rainy summer, subtropical; and the mean temperature of the hottest month is greater than $22^{\circ} \mathrm{C}$. Blumenau has a Cfa climate, constantly humid, subtropical, without a dry season and with hot summers (mean temperature of the hottest month is greater than $22^{\circ} \mathrm{C}$ ). Mean annual temperature ranges from
19.1 to $20.0^{\circ} \mathrm{C}$; monthly maximum temperatures range from 26.0 to $27.6^{\circ} \mathrm{C}$ and monthly minimum temperatures range from 15.4 to $16.8^{\circ} \mathrm{C}$ (Thomé et al., 1999). The greenhouse at FURB is made of alveolar polycarbonate and is shaded during part of the morning, whereas the greenhouse at UFLA is made of glass and is not shaded.

To establish the trap cultures, $500 \mathrm{~mL}$ of soil inoculum of each sample were mixed with $500 \mathrm{~mL}$ of sterile sand. This mixture was placed between two layers (200 $\mathrm{mL}$ each one) of sterile sand in $1.5 \mathrm{~kg}$ pots. Eighty seeds of palisade grass [Urochloa brizantha (Stapf) R.D.Webster] were sown and the plants were kept in a greenhouse for five months with application of Hoagland solution, with zero or $50 \%$ of the standard phosphorus (P) concentration, according to the nutritional needs of the plants in the initial stage. After the period of cultivation, the soil of each pot was homogenized and placed in cold storage at $4{ }^{\circ} \mathrm{C}$ until evaluation. Spores were extracted, mounted on slides, and identified according to the methodology described above. In addition, the presence of sporulating species was registered.

\section{Inoculum potential}

For evaluation of mycorrhizal inoculum potential, 20 $\mathrm{mL}$ of soil inoculum from each sample was placed in $90 \mathrm{~mL}$ of a mixture (1:1) of sterile soil and sand in plastic containers in duplicate for each compound field sample. Thirty seeds of Urochloa brizantha were added, and trimmed to 5 to 10 plants. Thirty days after establishment, the roots were separated from the substrate and washed, and $1 \mathrm{~g}$ of them was placed in capsules to be clarified and stained with trypan blue $(0.05 \%)$, according to the method of Koske and Gemma 
(1989). Determination of the mycorrhizal colonization percentage was estimated by the intersection method in a square laboratory dish (Giovannetti; Mosse, 1980) and used as an estimate of the mycorrhizal inoculum potential.

\section{Analysis of the AMF communities}

Analyses of diversity were performed on the PAST (PAleontological STatistics) scientific data analysis software (Hammer; Harper; Ryan, 2001), with the number of spores of each morphotype of AMF used as a measure of abundance for calculating the Shannon diversity index $\left(H^{\prime}\right)$, equitability $(\mathrm{J})$, and the Shannon index of each sample (H'sam). Species richness (R) was calculated as the number of species present in each environment, whereas mean species richness was obtained by the mean of the number of species obtained per sample. Relative abundance was calculated as the percentage of total spores from the environment represented by the species.

In regard to the frequency of occurrence of AMF in the environments, the species were classified, according to Zhang et al. (2004) and Assis et al. (2014), as Generalists (G), found in the soils of all environments; Intermediate (I), found in two to four environments; and Exclusive (E), found in the soil of only one environment. In regard to capture in different locations, species found in trap cultures at FURB and at UFLA were classified as present (1) or absent (0) in each environment.

\section{Statistical analyses}

The number of AMF spores and mycorrhizal colonization were transformed into $\log$ of $\mathrm{X}$, and the mean richness of species was transformed into square root of $\mathrm{X}$ prior to analyses. The difference among environments in regard to the number of spores, inoculum potential, and H'sam was evaluated through Analysis of Variance (ANOVA), followed by the Scott-Knott test at the level of $5 \%$ significance. Analyses were carried out using the Assistat statistical software (Silva; Azevedo, 2016).

Detrended Correspondence Analysis (DCA) was performed on the Canoco 4.5 software (Ter Braak; Smilauer, 1998) to determine gradient length. Since the gradient length obtained by DCA analysis was less than three, Principal Component Analysis (PCA) was carried out to show the ordering of the AMF species found in the five environments evaluated and to identify which soil properties were related to them (soil property data not shown since they belong to Patricia de Freitas Costa, not published). The five environments evaluated, the physical and chemical soil properties, and the AMF species were transformed into coordinates corresponding to their projection on the ordination axes, or eigenvalues, that represent the weight of each variable in each component (axis), with a correlation coefficient ranging from -1 to +1 . In this study, an eigenvalue of $\geq|0.4|$ was considered to indicate high association of the principal components.

\section{RESULTS AND DISCUSSION}

\section{Diversity and density of the spores directly extracted from the field}

A total of 31 AMF species distributed in 12 genera and seven families of Glomeromycota were identified (Table 2). It is noteworthy that among the AMF species found, this is the first report of the occurrence of the species Acaulospora nivalis and Acaulospora alpina in Brazil. Most of the species found ( $42 \%$ ) belong to the genus Acaulospora (13 species).

The highest mean species richness of AMF species was found in tailings piles (Figure 1), which was significantly different from the other environments. The highest R, J, H', and H'sam were found in tailings piles as well, whereas $\mathrm{CN}$ had the lowest values of R and H' (Table 2). As illustrated in Figure 1, spore density was not significantly different (evaluated at $5 \%$ significance) among the environments, and the overall mean was 586 spores $100 \mathrm{~mL}^{-1}$ of soil.

In general, the evaluated environments showed high mean spore density (Figure 1). This density may have been influenced by collection at the end of the dry period in Brazil, since water deficit can stimulate sporulation of AMF species (Ferreira; Carneiro; Saggin, 2012). In particular for the CE environment, the spore density found in this study was similar to that found by Fernandes et al. (2016) in Riparian forest in the Cerrado environment.

Among the species present in more than one environment, only those four that have relative abundance $<10 \%$ (Rhizophagus fasciculatus, Acaulospora lacunosa, A. sp0, and Ambispora leptoticha) were not found in direct extraction of field soil in tailings piles. Acaulospora mellea, A. morrowiae, and Glomus sp2 were found in all the environments and were thus considered Generalists in the environments studied. In direct extraction of field soil, 13 species of Exclusive AMF were found.

A higher number of Exclusive species was found in tailings piles (6), namely, Acaulospora alpina, Acaulospora nivalis, Acaulospora scrobiculata, Acaulospora sp1, Acaulospora tuberculata, and Septoglomus viscosum. CE had four Exclusive species, from four different genera (A. trappei, Dentiscutata heterogama, Redeckera fulvum, and Paraglomus occultum), while in the environments of FT, PE, and CN, only one Exclusive species was found: Rhizophagus diaphanus, Glomus sp1, and Dentiscutata biornata, respectively. 
Table 2: Arbuscular mycorrhizal fungi (AMF) species, relative abundance, frequency of occurrence (FO), equitability $(\mathrm{J})$, total Shannon indexes in the environment $\left(\mathrm{H}^{\prime}\right)$, mean of Shannon-Wiener indexes per sampling point $\left(\mathrm{H}^{\prime}\right.$ sam), and total species richness (R) in the environments of tailings piles replanted to grass (TP), Cerrado (CE), canga (CN), planted eucalyptus (PE), and forest (FT); - Spores not found, Generalist species (G), Exclusive species (E), Intermediate species (I).

\begin{tabular}{|c|c|c|c|c|c|c|}
\hline \multirow{2}{*}{ AMF species } & \multicolumn{5}{|c|}{ Relative Abundance } & \multirow[t]{2}{*}{ FO } \\
\hline & TP & CE & $\mathrm{CN}$ & $\mathrm{PE}$ & FT & \\
\hline \multicolumn{7}{|l|}{ Family Glomeraceae ${ }^{1}$} \\
\hline Dominikia sp & 9.61 & - & - & 0.68 & - & I \\
\hline Glomus magnicaule Hall & 0.58 & 0.40 & - & 0.55 & 0.05 & I \\
\hline Glomus microaggregatum ${ }^{6}$ Koske, Gemma \& Olexia & 0.11 & - & 0.04 & - & 0.09 & 1 \\
\hline Glomus sp1 & - & - & - & 0.37 & - & $\mathrm{E}$ \\
\hline Glomus sp2 & 33.1 & 87.46 & 84.85 & 82 & 81.4 & G \\
\hline Septog/omus viscosum (Nicolson) Walker, Redecker, Stille \& Schüssler & 11.19 & - & - & - & - & $\mathrm{E}$ \\
\hline Rhizophagus clarus (Nicolson \& Schenck) Walker \& Schuessler & 8.66 & 1.44 & - & 0.28 & 0.18 & I \\
\hline Rhizophagus diaphanus (Morton \& Walker) Walker \& Schuessler & - & - & - & - & 1.82 & $\mathrm{E}$ \\
\hline Rhizophagus fasciculatus (Thaxter) Walker \& Schuessler & - & 0.06 & - & 0.31 & - & I \\
\hline \multicolumn{7}{|l|}{ Family Gigasporaceae ${ }^{2}$} \\
\hline Gigasporaceae & - & 0.35 & - & 0.09 & 0.05 & I \\
\hline Gigaspora sp Gerd. \& Trappe & 0.16 & - & 0.53 & - & - & I \\
\hline Cetraspora pellucida (Nicol. \& Schenck) Oehl, Souza \& Sieverding & 0.74 & - & - & - & 0.05 & I \\
\hline Dentiscutata biornata (Spain, Sieverd. \& Toro) Sieverd., Souza \& Oehl & - & - & 0.08 & - & - & $\mathrm{E}$ \\
\hline Dentiscutata heterogama (Nicol. \& Gerd.) Sieverd., Souza \& Oehl & - & 0.40 & - & - & - & $\mathrm{E}$ \\
\hline \multicolumn{7}{|l|}{ Family Diversisporaceae ${ }^{3}$} \\
\hline Diversispora sp & 22.28 & - & 1.51 & 8.26 & 0.41 & I \\
\hline Redeckera fulvum (Berk. \& Broome) Walker \& Schuessler & - & 0.06 & - & - & - & $\mathrm{E}$ \\
\hline \multicolumn{7}{|l|}{ Family Acaulosporaceae ${ }^{2}$} \\
\hline Acaulospora alpina Oehl, Sykorova \& Sieverd & 1.00 & - & - & - & - & E \\
\hline Acaulospora colombiana (Spain \& Schenck) Kaonongbua, Morton \& Bever & 1.32 & 0.92 & - & 0.18 & - & I \\
\hline Acaulospora herrerae Furrazola, Goto, Silva, Sieverd. \& Oehl & 0.48 & - & - & 0.03 & - & I \\
\hline Acaulospora lacunosa Morton & - & - & 0.04 & - & 0.05 & I \\
\hline Acaulospora mellea Spain \& Schenck & 1.48 & 1.96 & 10.79 & 1.57 & 4.81 & G \\
\hline Acaulospora morrowiae Spain \& Schenck & 3.64 & 1.50 & 0.95 & 3.51 & 0.95 & G \\
\hline Acaulospora nivalis Oehl, Palenz., Sánchez, Silva \& Sieverd. & 0.42 & - & - & - & - & $\mathrm{E}$ \\
\hline Acaulospora scrobiculata Trappe & 2.75 & - & - & - & - & $\mathrm{E}$ \\
\hline Acaulospora spo & - & 2.54 & 1.29 & 2.07 & 9.71 & 1 \\
\hline Acaulospora sp1 & 0.16 & - & - & - & - & $\mathrm{E}$ \\
\hline Acaulospora spinosa Walker \& Trappe & 0.90 & - & - & - & 0.18 & 1 \\
\hline Acaulospora tuberculata Janos e Trappe & 0.32 & - & - & - & - & $\mathrm{E}$ \\
\hline Acaulospora walkeri Kramad. \& Hedger & 1.11 & - & - & - & 0.18 & I \\
\hline
\end{tabular}


Table 2: Continuation...

\begin{tabular}{|c|c|c|c|c|c|c|}
\hline \multirow{2}{*}{ AMF species } & \multicolumn{5}{|c|}{ Relative Abundance } & \multirow[t]{2}{*}{ FO } \\
\hline & TP & CE & $\mathrm{CN}$ & PE & FT & \\
\hline \multicolumn{7}{|l|}{ Family Archaeosporaceae ${ }^{4}$} \\
\hline Archaeospora trappei (Ames \& Linderman) Morton \& Redecker & - & 1.96 & - & - & - & $\mathrm{E}$ \\
\hline \multicolumn{7}{|l|}{ Family Ambisporaceae ${ }^{5}$} \\
\hline Ambispora leptoticha (Schenck \& Sm.) Walker Vestberg \& Schuessler & - & 0.06 & - & 0.09 & 0.05 & 1 \\
\hline \multicolumn{7}{|l|}{ Family Paraglomeraceae ${ }^{4}$} \\
\hline Paraglomus occultum (Walker) Morton \& Redecker & - & 0.87 & - & - & - & $\mathrm{E}$ \\
\hline $\mathrm{H}^{\prime} \mathrm{sam}^{*}$ & $1.581 \mathrm{a}$ & $0.641 \mathrm{k}$ & $0.477 \mathrm{~b}$ & $0.607 k$ & $0.658 \mathrm{~b}$ & \\
\hline $\mathrm{H}^{\prime}$ & 2.02 & 0.650 & 0.582 & 0.776 & 0.737 & \\
\hline J & 0.6744 & 0.246 & 0.265 & 0.294 & 0.272 & \\
\hline $\mathrm{R}$ & 20 & 14 & 9 & 14 & 15 & \\
\hline
\end{tabular}

${ }^{1}$ Pirozynski and Dalpé modified by Walker and Schuessler; ${ }^{2}$ Morton and Benny; ${ }^{3}$ Walker and Schuessler; ${ }^{4}$ Morton and Redecker; ${ }^{5}$ Walker, Vestberg and Schuessler; ${ }^{6}$ Presence of the species, since many spores are present within other spores. *Values followed by the same letters do not differ statistically by the Scott-Knott test at the level of $5 \%$ significance.

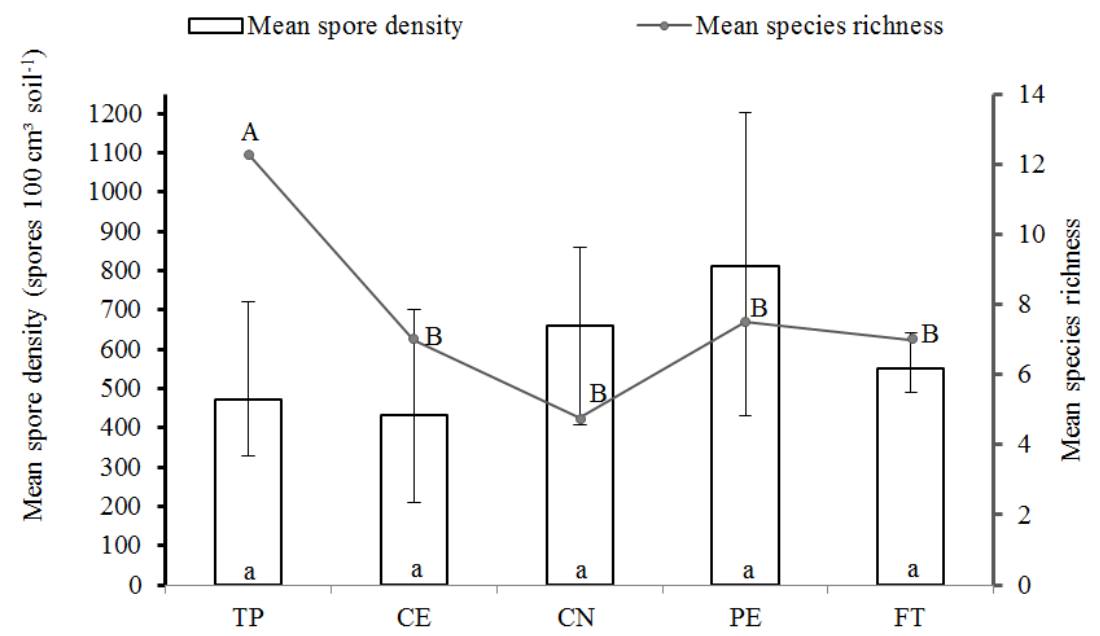

Figure 1: Mean spore density of arbuscular mycorrhizal fungi with error bars and mean species richness in the environments of tailings piles replanted to grass (TP), Cerrado (CE), canga (CN), planted eucalyptus (PE), and forest (FT). Mean values followed by the same lowercase letter for spore density and uppercase letters for species richness do not differ statistically by the Scott-Knott test at the level of 5\% significance.

The most abundant genus in all the environments was Glomus, followed by Diversispora and Acaulospora in TP and by Acaulospora in the other environments (Figure 2A). The greater abundance of Glomus is due to the species Glomus sp2 having represented from
$76 \%$ (TP) to more than $98 \%$ (other environments) of the spores of this genus. Seven genera and one family whose spores could not be identified at the genus level represented less than $4 \%$ of the spores of the environments evaluated (Figure 2B). 

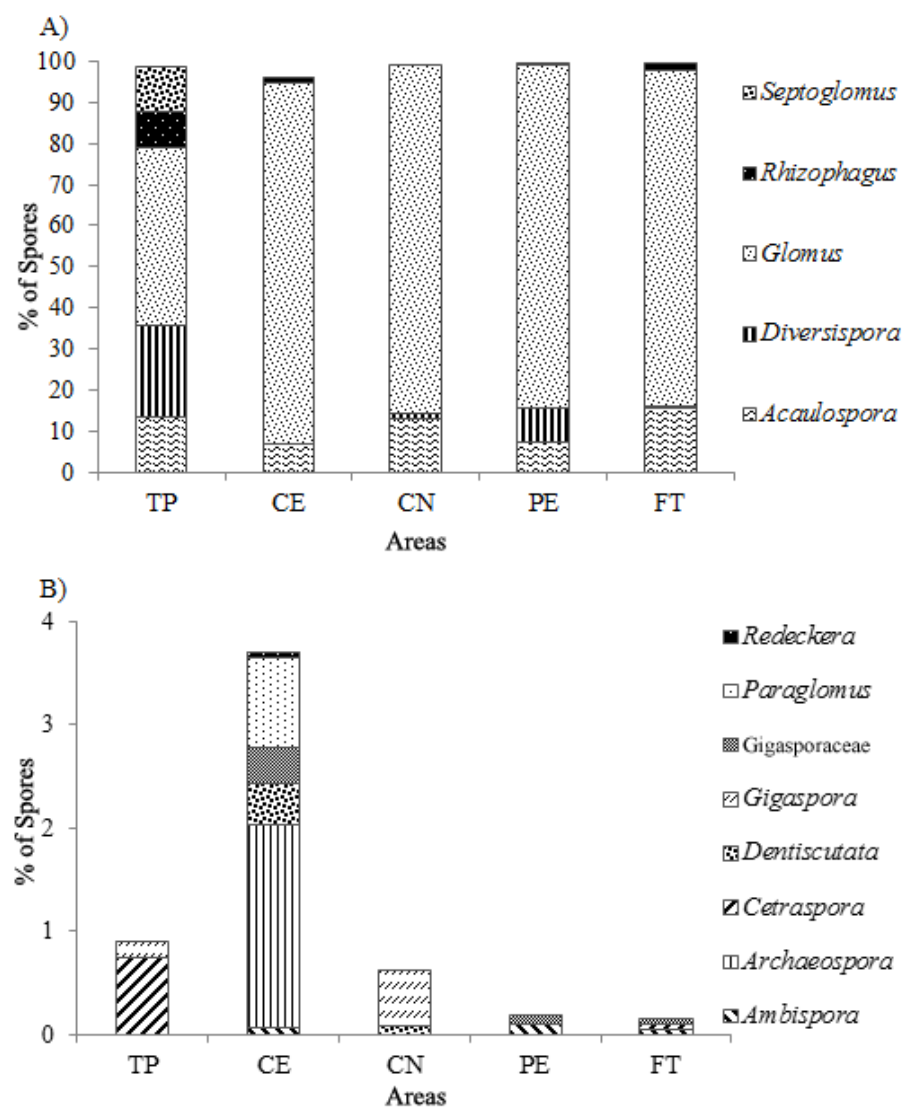

Figure 2: Percentage of spores of arbuscular mycorrhizal fungi per genus. A) Most abundant genera found in the environments evaluated. B) Least abundant genera found in the environments evaluated. In the environments of tailings piles replanted to grass (TP), Cerrado (CE), canga (CN), planted eucalyptus (PE), and forest (FT).

Silva et al. (2015), evaluating altitude gradients in the Serra do Cipó in the Cerrado biome, identified 51 species of AMF, and the most representative genera were Glomus and Acaulospora. Some isolates were obtained in pure culture and deposited in the International Culture Collection of Glomeromycota (CICG) (www.furb.br/cicg - Blumenau, Santa Catarina, Brazil). From the canga environment, the following species were deposited: Gigaspora gigantea (code MGR320A), Acaulospora mellea (code MGR320B), Dentiscutata biornata (code MGR320C), Cetraspora sp (code MGR320E), Dentiscutata heterogama (code MGR321A), Acaulospora mellea (code MGR321D), and Ambispora leptoticha (code MGR321G). From the forest environment Ambispora leptoticha (code MGR322A) was deposited. These isolates can contribute to future studies of the application of these species.
The variability in AMF species richness can be explained by the different types of vegetation found in these environments, even though they are near one another (except for CN). Carvalho et al. (2012), evaluating different areas of rocky fields belonging to the Cerrado biome, also found variability in the diversity of AMF species among the sampled areas, and the authors attributed such a variation to the heterogeneity among the habitats evaluated. A richness of AMF species from 6 to 13 was detected in areas affected by mining in the United States (Kiernan; Hendrix; Maronek, 1983), India (Raman et al., 1993), and Brazil (Melloni; Siqueira; Moreira, 2003; Mergulhão et al., 2010); these values are lower than the ones detected in this study (20). Inocula from different areas may have been added to tailings piles in the process of their construction, and the higher diversity found there may be explained by heterogeneity among the piles and by the mixture of materials in their construction (Unpublished data of Diego Tassinari). 
The genus Acaulospora, the second most abundant genus in all the areas, except for TP, has been reported as the second most representative genus in forest ecosystems in the Caatinga biome (Stürmer; Siqueira, 2008). In contrast, the high relative abundance of the species Glomus sp2 may have contributed not only to the Glomus genus being the most abundant among the environments evaluated, but also to the lower values of $\mathrm{J}$ found in the four environments in relation to tailings piles, since these aspects are influenced by the homogeneity of distribution of the number of individuals in the species. The dominance of 2 to $3 \mathrm{AMF}$ species in AMF communities is commonly found in other Brazilian ecosystems (Stürmer; Siqueira, 2008). Spore numbers provide indirect evidence of increased carbon partitioning for reproduction of AMF species (Gazey; Abbott; Robson, 1992), although spore biovolume is probably a more accurate measure of resource allocation to sporulation when spores of a species assemblage are of unequal size (Morton; Bentivenga; Bever, 1995).

While generalist species exhibit plasticity to the different conditions of the ecosystems evaluated, the occurrence of exclusive species in determined environments evaluated may be related to specific conditions that can favor sporulation of these species in these environments (Rosendahl, 2008), such as the plant species present and other factors not evaluated in this study.

\section{Soil properties related to the AMF species found in the field}

Through PCA, soil properties highly associated with the occurrence of AMF species in principal components (PC) 1 and 2 were identified (Table 3 and Figure 3). The four PC were responsible for $72.7 \%$ of total species variation, with PC 1 and PC 2 being responsible for $32.4 \%$ and $13.1 \%$ of the total variation, respectively.

$\mathrm{PC} 1$, which in its positive variation is influenced by $\mathrm{pH}, \mathrm{S}, \mathrm{P}$, and $\mathrm{SB}$, vertically segregated the TP environment from the others (Figure 3), indicating that the environment in rehabilitation differs from the others mainly in relation to the values of these soil properties. The other environments were associated with the O.M., $\mathrm{K}$, and $\mathrm{Cu}$ contents by $\mathrm{PC} 1$. Lower values of $\mathrm{pH}$ separated $\mathrm{FT}$, along with the other unmined environments, from the environments of TP in rehabilitation. Most of the species found (18) are more associated with the environments of TP and with the properties that segregated them. In the same way, the distribution of the other 14 species with the chemical properties associated with the other environments is related to greater or lesser intensity according to their proximity to the axis; the nearer to the axis, the greater the intensity.

PC 2 (Figure 3) is mainly related to the contents of $\mathrm{B}$ and $\mathrm{K}$. This PC divided the four sampling points of TP in two sectors, showing the variability of species even within the system of rehabilitation and also separated some sampling points of PE and CE, whereas FT and CN remained clustered.

The distance of Glomus sp2 from the area influenced by $\mathrm{pH}, \mathrm{S}$, and $\mathrm{P}$ indicates that its higher sporulation is not related to increases in the values of these soil properties. In contrast, most of the species of Acaulospora were influenced by these factors. The species $A$. morrowiae and G. magnicaule are quite close to the zero value of $\mathrm{PC} 1$, thus without influence of the $\mathrm{pH}, \mathrm{K}, \mathrm{P}, \mathrm{SB}, \mathrm{O} . \mathrm{M}$., $\mathrm{Cu}$, and $\mathrm{S}$ properties that determine this $\mathrm{PC}$, just as Gigaspora sp, which proved to be quite near the zero value of both the PCs. Simultaneously, spores of the family Gigasporaceae, Ambispora leptoticha, Rhizophagus fasciculatus, Acaulospora sp0, Glomus sp2, A. mellea, and A. lacunosa are more strongly associated with environments $\mathrm{CE}, \mathrm{PE}, \mathrm{CN}$, and $\mathrm{FT}$ and with the soil properties that distinguish them.

Although the species Glomus sp2 was less associated with TP, it corresponds to the expressive part of the spores found in this environment. However, the percentage represented by this species in the other environments was greater, whereas TP was the environment with highest J (Table 2).

Table 3: Eigenvalues of soil properties resulting from Principal Component Analysis.

\begin{tabular}{|c|c|c|c|c|c|c|c|c|}
\hline Variables ${ }^{1}$ & $\mathrm{pH}$ & K & $P$ & $\mathrm{SB}^{2}$ & O.M. ${ }^{3}$ & $\mathrm{Cu}$ & B & S \\
\hline Factor 1 & 0.897 & -0.492 & 0.688 & 0.570 & -0.546 & -0.449 & 0.205 & 0.781 \\
\hline Factor 2 & 0.212 & -0.448 & -0.177 & -0.020 & -0.330 & 0.257 & -0.489 & -0.306 \\
\hline
\end{tabular}

${ }^{1}$ Values of other chemical properties evaluated were not shown since they did not have eigenvalues $\leq|0.4|$. ${ }^{2}$ SB - Sum of bases; O.M. ${ }^{3}$ - organic matter. Soil properties that had eigenvalues $\geq|0.4|$ were considered indicative of high association of the principal components. 


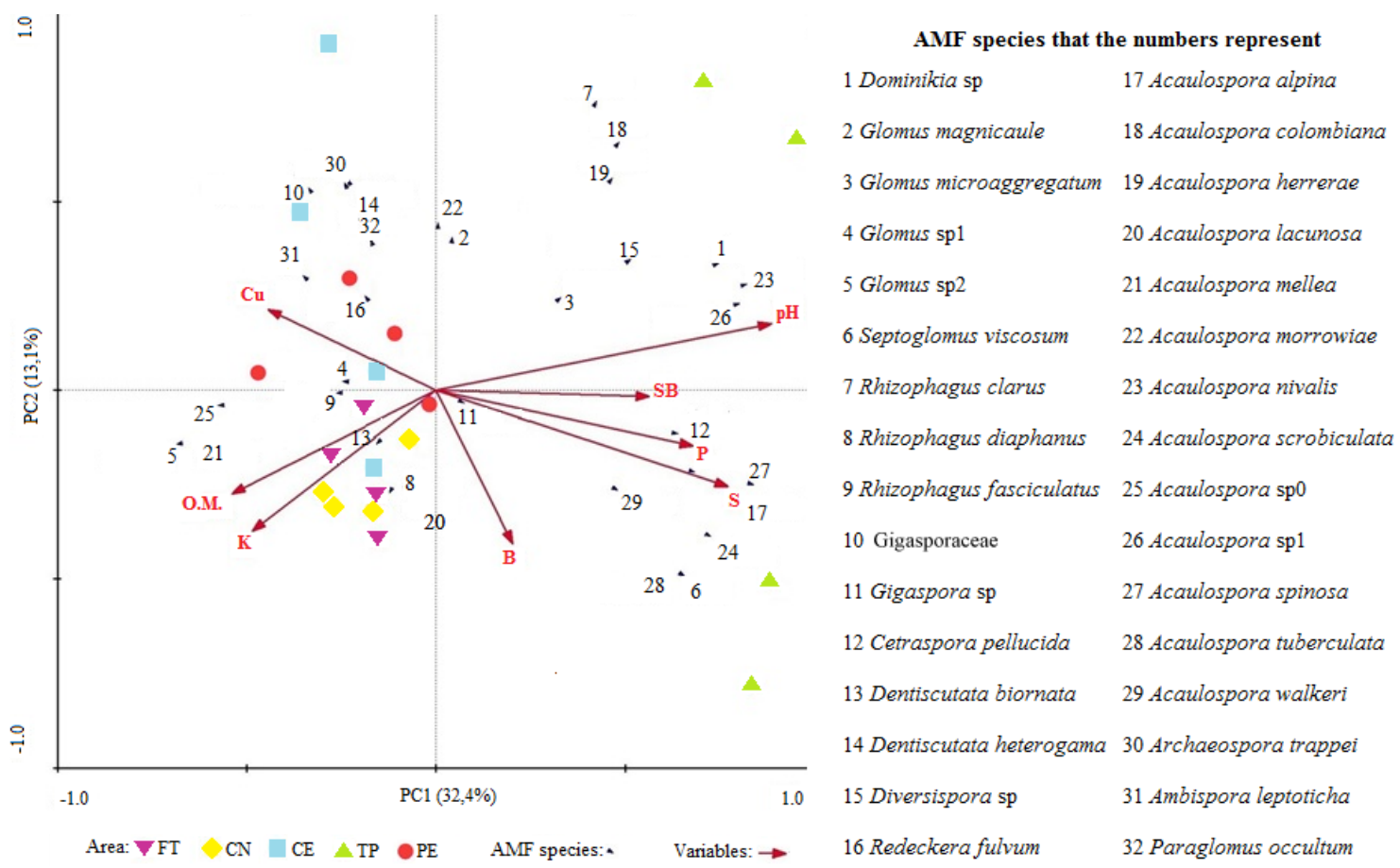

Figure 3: Ordination diagram of Principal Component Analysis of soil properties related to the ordination axes $(\geq|0.4|$ eigenvalue) for the five environments studied: forest (FT), canga (CN), Cerrado (CE), tailings piles replanted to grass (TP), and planted eucalyptus (PE), and related to 32 arbuscular mycorrhizal fungi (AMF) species found by direct extraction in the field.

Among the soil properties evaluated as determinant in distribution of species in the environments, none of the physical properties showed a high relation regarding ordination of the axes in PCA (Table 3); this was also the result obtained by Carvalho et al. (2012) in a study of rocky field areas. The relation of chemical properties may be linked to the different degrees of human interference and different vegetation patterns. Clustering of the FT and $\mathrm{CN}$ points shows the greatest similarity among the sampling units; these are natural environments with little or no human activity.

Correction of soil acidity, which was probably performed at the beginning of rehabilitation of the area, can affect sporulation of AMF species and promote modifications in the structuring of the AMF communities. However, the response varies among the species (Van der Heyde et al., 2017). Siqueira, Colozzi-Filho and Oliveira (1989) showed that the genus Acaulospora is generally associated with lower values of $\mathrm{pH}$ (less than 6.5). The result of PCA also indicates that values of $\mathrm{pH}$ below 5.0 may not be adequate for species of this genus. The species A. morrowiae was indifferent to $\mathrm{P}$ concentrations in the soil, which corroborates the results of Rocha, Oliveira and Carvalho (1994).

Each environment evaluated showed a certain diversity of species intrinsic to the environment. As the diversity of AMF species can influence the plant community, increasing it over successive stages (Van der Heijden et al., 1998), greater richness of species, as well as $\mathrm{H}$ ' and $\mathrm{J}$ found in TP, can favor the establishment of diverse plants used for recovery of degraded areas, allowing the area to advance in the rehabilitation process. Acaulospora morrowiae, the unique Generalist species among all the evaluations, is reported as having wide presence in diverse environments, and may even have a plant protective effect in soils contaminated with heavy metals (Carvalho et al., 2012; Klauber-Filho; Siqueira; Moreira, 2002; Rangel et al., 2014). In addition, its presence in the rehabilitation environment may contribute to revegetation of the area.

\section{Diversity of spores in trap cultures}

Considering both locations (UFLA and FURB) used for carrying out TCs, a total of 49 species were captured (Table 4). Among them, 28 were not captured 
in field samples, thus leading to an increase of more than $90 \%$ in the total number of species in relation to direct extraction from the soil in the field. The only species found both in the field and in the TCs considering all the environments was Acaulospora morrowiae. Fourteen species were captured in environments in addition to those where they were found by direct extraction from the field.

Table 4: Arbuscular mycorrhizal fungi species found in Trap Cultures (TCS), their occurrence at the Universidade Federal de Lavras (UFLA) and the Universidade Regional de Blumenau (FURB) ( 1 = presence of species; $0=$ absence of species), and total species richness (R) in tailings piles replanted to grass (TP), Cerrado (CE), canga (CN), planted eucalyptus (PE), and Forest (FT), or species not found in direct extraction in the field (N).

\begin{tabular}{|c|c|c|c|c|c|c|c|c|c|c|c|}
\hline \multirow{2}{*}{ AMF species in TCs } & \multicolumn{5}{|c|}{ UFLA } & \multicolumn{5}{|c|}{ FURB } & \multirow{2}{*}{$\begin{array}{l}\text { Site of direct } \\
\text { extraction }\end{array}$} \\
\hline & TP & CE & $\mathrm{CN}$ & $\mathrm{PE}$ & FT & TP & $\mathrm{CE}$ & $\mathrm{CN}$ & $\mathrm{PE}$ & FT & \\
\hline \multicolumn{12}{|l|}{ Family Archaeosporaceae } \\
\hline Archaeospora trappei & 0 & 0 & 0 & 0 & 1 & 1 & 1 & 1 & 0 & 0 & CE \\
\hline \multicolumn{12}{|l|}{ Family Ambisporaceae } \\
\hline Ambispora leptoticha & 0 & 1 & 1 & 1 & 1 & 1 & 1 & 0 & 1 & 1 & CE PE FT \\
\hline \multicolumn{12}{|l|}{ Family Acaulosporaceae } \\
\hline Acaulospora alpina & 0 & 0 & 0 & 0 & 1 & 1 & 0 & 0 & 0 & 1 & $\mathrm{TP}$ \\
\hline Acaulospora colombiana & 0 & 1 & 0 & 0 & 0 & 1 & 1 & 0 & 0 & 1 & TP CE PE \\
\hline Acaulospora delicata Walker, Pfeiffer \& Bloss & 0 & 0 & 0 & 0 & 0 & 1 & 1 & 0 & 1 & 0 & $\mathrm{~N}$ \\
\hline Acaulospora foveata Trappe \& Janos & 0 & 0 & 0 & 0 & 0 & 0 & 1 & 1 & 1 & 0 & N \\
\hline Acaulospora lacunosa & 0 & 0 & 0 & 0 & 1 & 0 & 1 & 1 & 0 & 1 & CN FT \\
\hline Acaulospora mellea & 1 & 1 & 0 & 1 & 1 & 1 & 1 & 1 & 1 & 1 & TP CN PE FT \\
\hline Acaulospora morrowiae & 1 & 1 & 1 & 1 & 1 & 1 & 1 & 1 & 1 & 1 & TP CN PE FT \\
\hline Acaulospora rehmii Sieverd. \& Toro & 1 & 0 & 0 & 0 & 1 & 1 & 0 & 0 & 0 & 1 & $\mathrm{~N}$ \\
\hline Acaulospora scrobiculata & 1 & 0 & 1 & 0 & 1 & 1 & 0 & 0 & 0 & 1 & $\mathrm{TP}$ \\
\hline Acaulospora sp1 & 0 & 0 & 0 & 0 & 0 & 1 & 0 & 0 & 0 & 1 & N \\
\hline Acaulospora sp2 & 0 & 0 & 0 & 0 & 0 & 0 & 1 & 0 & 1 & 1 & $\mathrm{~N}$ \\
\hline Acaulospora spinosa & 1 & 0 & 0 & 0 & 0 & 1 & 0 & 0 & 0 & 1 & TP FT \\
\hline $\begin{array}{l}\text { Acaulospora spinosissima Oehl, Palenz. } \\
\text { I.C. Sánchez, Tchabi, Hount. \& G.A. Silva }\end{array}$ & 0 & 0 & 0 & 0 & 0 & 1 & 0 & 0 & 0 & 1 & $\mathrm{~N}$ \\
\hline \multicolumn{12}{|l|}{ Family Diversisporaceae } \\
\hline $\begin{array}{l}\text { Corymbig/omus tortuosum (N.C Schenck \& } \\
\text { G.S. Sm.) Blaszk. Et Chwat }\end{array}$ & 0 & 0 & 0 & 0 & 0 & 0 & 1 & 0 & 0 & 0 & $\mathrm{~N}$ \\
\hline Diversispora sp. & 1 & 0 & 1 & 1 & 0 & 1 & 0 & 1 & 1 & 1 & TP CN PE FT \\
\hline \multicolumn{12}{|l|}{ Family Gigasporaceae } \\
\hline Cetraspora pellucida & 1 & 0 & 0 & 0 & 0 & 0 & 0 & 1 & 0 & 0 & TP FT \\
\hline Dentiscutata biornata & 0 & 0 & 1 & 0 & 0 & 0 & 1 & 1 & 0 & 0 & $\mathrm{CN}$ \\
\hline Dentiscutata heterogama & 0 & 0 & 1 & 1 & 0 & 1 & 0 & 0 & 0 & 0 & CE \\
\hline Dentiscutata cf. scutata & 1 & 0 & 0 & 0 & 0 & 1 & 1 & 1 & 0 & 1 & $\mathrm{~N}$ \\
\hline Gigaspora albida Schenck \& Smith & 0 & 0 & 0 & 0 & 0 & 1 & 0 & 0 & 1 & 1 & $\mathrm{~N}$ \\
\hline $\begin{array}{l}\text { Gigaspora gigantea (Nicolson \& } \\
\text { Gerdemann) Gerd. \& Trappe }\end{array}$ & 0 & 0 & 0 & 0 & 0 & 0 & 0 & 1 & 0 & 0 & $\mathrm{~N}$ \\
\hline Gigaspora sp. & 1 & 0 & 0 & 0 & 0 & 0 & 0 & 0 & 0 & 0 & TP CN \\
\hline
\end{tabular}


Table 4: Continuation...

\begin{tabular}{|c|c|c|c|c|c|c|c|c|c|c|c|}
\hline \multirow{2}{*}{ AMF species in TCs } & \multicolumn{5}{|c|}{ UFLA } & \multicolumn{5}{|c|}{ FURB } & \multirow{2}{*}{$\begin{array}{l}\text { Site of direct } \\
\text { extraction }\end{array}$} \\
\hline & TP & CE & $\mathrm{CN}$ & $\mathrm{PE}$ & FT & TP & CE & $\mathrm{CN}$ & $\mathrm{PE}$ & $\mathrm{FT}$ & \\
\hline $\begin{array}{l}\text { Scutellospora pernambucana Oehl, Silva, } \\
\text { Freitas \& Maia }\end{array}$ & 0 & 0 & 0 & 0 & 0 & 0 & 1 & 0 & 0 & 1 & $\mathrm{~N}$ \\
\hline \multicolumn{12}{|l|}{ Family Claroideoglomeraceae ${ }^{1}$} \\
\hline $\begin{array}{l}\text { Claroideoglomus etunicatum (W.N. Becker } \\
\text { \& Gerd.) C. Walker \& A. Schüssler }\end{array}$ & 0 & 0 & 0 & 0 & 0 & 1 & 0 & 0 & 0 & 0 & $\mathrm{~N}$ \\
\hline \multicolumn{12}{|l|}{ Family Glomeraceae } \\
\hline Dominikia sp. & 1 & 1 & 1 & 1 & 0 & 1 & 1 & 0 & 1 & 1 & TP PE \\
\hline Glomus cf. aggregatum & 1 & 0 & 0 & 0 & 0 & 0 & 0 & 0 & 0 & 1 & $\mathrm{~N}$ \\
\hline Glomus glomerulatum Sieverd. & 0 & 0 & 0 & 1 & 1 & 1 & 1 & 1 & 1 & 1 & $\mathrm{~N}$ \\
\hline Glomus cf. invermaium & 1 & 0 & 0 & 0 & 0 & 0 & 0 & 0 & 0 & 0 & $\mathrm{~N}$ \\
\hline Glomus microaggregatum & 0 & 0 & 0 & 0 & 0 & 1 & 0 & 1 & 1 & 1 & $\mathrm{TP}, \mathrm{CN}, \mathrm{FT}$ \\
\hline Glomus microcarpum Tulasne \& Tulasne & 0 & 0 & 0 & 0 & 0 & 0 & 1 & 1 & 0 & 1 & $\mathrm{~N}$ \\
\hline Glomus sp2 & 1 & 1 & 1 & 1 & 1 & 0 & 0 & 0 & 0 & 0 & $\mathrm{~T}$ \\
\hline Glomus sp3 & 0 & 1 & 0 & 1 & 1 & 0 & 0 & 0 & 0 & 0 & $\mathrm{~N}$ \\
\hline Glomus sp4 & 1 & 0 & 1 & 0 & 0 & 0 & 0 & 0 & 0 & 0 & $\mathrm{~N}$ \\
\hline Glomus sp5 & 0 & 0 & 1 & 0 & 0 & 0 & 0 & 0 & 0 & 0 & $\mathrm{~N}$ \\
\hline Glomus sp6 & 0 & 0 & 0 & 0 & 0 & 1 & 0 & 0 & 1 & 1 & $\mathrm{~N}$ \\
\hline Glomus sp7 & 0 & 0 & 0 & 0 & 0 & 0 & 0 & 0 & 0 & 1 & $\mathrm{~N}$ \\
\hline Glomus sp8 & 0 & 0 & 0 & 0 & 0 & 1 & 0 & 0 & 0 & 1 & $\mathrm{~N}$ \\
\hline Glomus spinuliferum Sieverding \& Oehl & 0 & 0 & 0 & 0 & 0 & 1 & 1 & 0 & 0 & 0 & $\mathrm{~N}$ \\
\hline Rhizophagus clarus & 1 & 0 & 0 & 1 & 0 & 1 & 1 & 0 & 0 & 1 & TP CE PE FT \\
\hline $\begin{array}{l}\text { Rhizophagus fasciculatus (Thaxter) C. } \\
\text { Walker \& A. Schüssler }\end{array}$ & 0 & 0 & 0 & 0 & 0 & 1 & 1 & 0 & 1 & 1 & $C E, P E$ \\
\hline Rhizophagus diaphanus & 1 & 1 & 1 & 1 & 1 & 0 & 0 & 0 & 0 & 0 & FT \\
\hline Sclerocystis coremioides Berk. \& Broome & 0 & 0 & 0 & 0 & 0 & 1 & 1 & 1 & 0 & 1 & $\mathrm{~N}$ \\
\hline Sclerocystis taiwanensis C.G. Wu \& Z. C. Chen & 0 & 0 & 0 & 0 & 0 & 0 & 0 & 0 & 0 & 1 & $\mathrm{~N}$ \\
\hline Sclerocystis sinuosa Gerd \& B.K. Bakshi & 0 & 0 & 0 & 0 & 0 & 0 & 0 & 0 & 0 & 1 & $\mathrm{~N}$ \\
\hline Septoglomus sp1 & 0 & 0 & 0 & 0 & 0 & 1 & 0 & 0 & 0 & 0 & $\mathrm{~N}$ \\
\hline Septoglomus viscosum & 0 & 1 & 1 & 1 & 1 & 1 & 1 & 1 & 1 & 1 & $\mathrm{TP}$ \\
\hline \multicolumn{12}{|l|}{ Incertae sedis } \\
\hline Entrophospora infrequens (Hall) Ames \& Schneid & 1 & 0 & 0 & 0 & 0 & 1 & 1 & 0 & 0 & 1 & $\mathrm{~N}$ \\
\hline$\underline{\mathrm{R}}$ & 17 & 9 & 12 & 12 & 13 & 29 & 22 & 15 & 14 & 31 & \\
\hline
\end{tabular}

${ }^{1}$ Walker \& Schüssler.

The capture of species only in TCs and not from direct extractions in the field shows the importance of this technique for studies of AMF diversity since some species may exhibit low or no sporulation in the field (Stutz; Morton, 1996). Some species for which spores had not previously been found in the field sporulated in
TCs, showing that there were viable propagules able to establish association with the trap species (U. brizantha). In contrast, some species whose spores were found in the field were not captured in TCs. This may be explained by the low density of spores of some AMF species found in the field, and may also be due to the preferences of 
the trap species itself since the host plant is able to show preference for AMF species that are more efficient in the association (Bever et al., 2009).

It is believed that the species Glomus sp2 has greater capability of establishing association with plants and sporulating under the climate conditions of the TCs at UFLA, since it did not sporulate in TCs at FURB. Since this species was found in a higher number of spores in all field areas, it may also have preferentially colonized the roots of the trap species in detriment to other species present, as reported by Bever et al. (2009). Thus, the TCs at UFLA captured a much lower number of species. However, the greater richness of species captured at FURB may have been determined by the fact that the greenhouse was shaded part of the day and that environmental conditions at this site are quite different from those of the Quadrilátero Ferrífero compared to UFLA. As the AMF species respond in different manners and have different tolerances depending on the disturbance (Van der Heyde et al., 2017), the sporulation of a greater number of species at FURB may be due to the response of the AMF species in overcoming adversity and surviving under environment conditions different from their conditions of origin. Lower insolation at FURB may have resulted in milder temperatures, allowing better development of the plants and, consequently, greater investment in mycorrhization on the part of the host plant.

The TCs at UFLA were able to capture 28 AMF species, whereas at FURB, 43 were captured; a considerable increase in species richness could be observed with the use of TCs under different environmental conditions (Table 5). The species Rhizophagus diaphanus and Glomus sp2 sporulated in all the TCs at UFLA and did not sporulate at FURB.

Table 5: Species richness of arbuscular mycorrhizal fungi and increases in species richness by the use of trap cultures (TCS) at the Universidade Federal de Lavras (UFLA) and the Universidade Regional de Blumenau (FURB) in soils from tailings piles replanted to grass (TP), Cerrado (CE), canga (CN), planted eucalyptus (PE), and forest (FT).

\begin{tabular}{cccccc}
\hline & TP & CE & CN & PE & FT \\
\hline Direct extraction from soil & 20 & 14 & 9 & 14 & 15 \\
Richness increases TCs UFLA & 7 & 3 & 8 & 5 & 7 \\
Richness increases TCs FURB & 18 & 15 & 9 & 8 & 23 \\
Total richness increases TCs & 22 & 17 & 16 & 11 & 25 \\
Total richness & 42 & 31 & 25 & 25 & 40 \\
\hline
\end{tabular}

Canga, when evaluated only by field spores, exhibited lower R and H'; however, when evaluated in TCs (Table 5), species richness equal to that of the PE area was observed. The TP environment, when only field spores were evaluated, was the environment that exhibited the highest R, followed by FT and CE, and the highest H'. A total of 59 species were found in all the environments considering TCs and direct extraction from the field and, among them, 15 could not be identified at the species level.

The lower diversity of AMF spores found in $\mathrm{CN}$ may be related to scarcity of soil and other factors that hinder establishment of plants in these environments (Skirycz et al., 2014). In a similar way, in PE, the lower diversity of plant species may have influenced the lower diversity of AMF spores. Thus, as these fungi are necessarily biotrophic, the stability of the ecosystems in regard to the constant presence of hosts can ensure the survival of AMF species (Siqueira; Colozzi-Filho; Oliveira, 1989). Even though lower in relation to CP, $\mathrm{CE}$, and FT, the diversity of AMF spores found in $\mathrm{CN}$ is the greatest yet reported so far in studies of these areas and may be contributing to conservation of this environment.

Although disturbances affect soil properties and may diminish the diversity of AMF (Lins et al., 2006), higher R and H' found in TP in the field, as well as greater total richness of species, indicate that AMF diversity was not only recovered, but also increased in the area in rehabilitation. Since there is preferentiality between macro- and microsymbionts in mycorrhizas (Bever et al., 2009; Kiers et al., 2011), this greater diversity of AMF species can facilitate the entrance of mycotrophic plant species in the area, thus assisting the continuity of its rehabilitation process.

Considering that there are currently only 289 species of AMF described worldwide (Goto, 2017), the species described in this study represent $15 \%$ of all species, showing that these areas are hotspots of diversity of AMF.

\section{Inoculum potential}

Inoculum potential differed among the environments evaluated (Figure 4), with the $\mathrm{CN}$ area showing the highest potential, with $39.9 \%$ of the roots with colonization. The $\mathrm{CE}$ area exhibited the second highest inoculum potential, with $22.7 \%$ of the roots colonized, whereas the other areas did not differ among themselves and exhibited inoculum with lower potential for colonization, with fewer than $13 \%$ of roots colonized by AMF. 


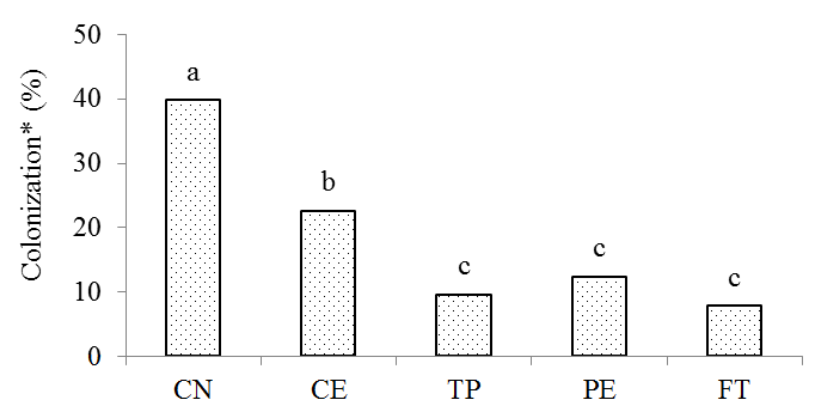

Figure 4: Mycorrhizal inoculum potential given by the percentage of mycorrhizal colonization of arbuscular mycorrhizal fungi in Urochloa brizantha inoculated with soil from the environments of tailings piles replanted to grass (TP), Cerrado (CE), canga (CN), planted eucalyptus (PE), and forest (FT). * Mean values followed by the same lowercase letters do not differ statistically by the Scott-Knott test at the level of 5\% significance.

The viability of AMF propagules in the soil can decrease in accordance with the disturbance to which they are subjected, thus reducing their infective capacity (Trejo; Barois; Sangabriel-Conde, 2016). However, the infective capacity of the AMF species is not related to propagule density (Caproni et al., 2003; Santos et al., 2000), since it infective capacity was not correlated with spore density in the present study. In contrast, dormancy of the spores varies considerably among species (Juge et al., 2002). Greater infectivity of the inocula of $\mathrm{CN}$ shows that although $\mathrm{CN}$ exhibits the lowest diversity of species and has spore density similar to the other environments, the inocula quickly colonize the host and can assist in the resilience of this environment subject to stress factors.

\section{CONCLUSIONS}

The tailings piles in rehabilitation with molasses grass exhibits greater diversity of AMF species in relation to the other environments evaluated, and can facilitate introduction of new plants in the rehabilitation process. The greater potential of mycorrhizal inoculum in the canga environment can contribute to resilience in this area. The use of Trap Cultures in both locations of Brazil increases the diversity of AMF species captured insofar as different species tend to develop better under distinct environmental conditions. The distribution of some AMF species is better explained by chemical properties of the soil, such as $\mathrm{pH}$ and exchangeable contents of $\mathrm{S}$ and $\mathrm{P}$. The iron mining area and its surroundings are hotspots of AMF diversity, and noteworthy in this study is the first report of the occurrence of Acaulospora nivalis and Acaulospora alpina in Brazil.

\section{ACKNOWLEDGMENTS}

The authors are grateful to the project CRA - RDP - 00136 - 10 (FAPEMIG/ FAPESP/ FAPESPA/ VALE S. A.), "Diversity of plants and soil organisms with biotechnological potential and indicators of environmental recovery in Minas Gerais"; to Vale for financial support; to Fernanda de Carvalho; to Capes, FAPEMIG, and CNPq for financial assistance and scholarships. SLS, MACC, and FMSM thank the CNPq [SLS: 309163/2015-3; MACC: 308105/2014-1; FMSM: 304527/2016-5] and FAPEMIG [MACC: APQ-01661-16] for research productivity scholarships.

\section{REFERENCES}

ASSIS, P. C. R. et al. Fungos micorrízicos arbusculares em campos de murundus após a conversão para sistemas agrícolas no cerrado. Revista Brasileira de Ciência do Solo, 38(1):1703-1711, 2014.

BEVER, J. D. et al. Preferential allocation to beneficial symbiont with spatial structure maintains mycorrhizal mutualism. Ecology Letters, 12(1):13-21, 2009.

BŁASZKOWSKI, J. Glomeromycota. Kraków, Poland: W. Szafer Institute of Botany, Polish Academy of Sciences, 2012. 303p.

BRASIL. DNPM (Departamento Nacional de Produção Mineral). 2014. Available in: <http://www.dnpm.gov.br/dnpm/sumarios/ sumario-mineral-2014>. Access in: June, 20, 2016.

BRASIL. MMA (Ministério do Meio Ambiente). 2015. Available in: <http://www.mma.gov.br/biomas/cerrado>. Access in: October, 16, 2015.

CABRAL, L. et al. Arbuscular mycorrhizal fungi in phytoremediation of contaminated areas by trace elements: Mechanisms and major benefits of their applications. World Journal of Microbiology and Biotechnology, 31(11):1655-1664, 2015.

CAPRONI, A. L. et al. Capacidade infectiva de fungos micorrízicos arbusculares em áreas reflorestadas após mineração de bauxita no Pará. Pesquisa Agropecuária Brasileira, 38(8):937-945, 2003.

CARVALHO, F. et al. The mosaic of habitats in the high-altitude Brazilian rupestrian fields is a hotspot for arbuscular mycorrhizal fungi. Applied Soil Ecology, 52:9-19, 2012.

CARVALHO FILHO, A. de; CURI, N.; SHINZATO, E. Relações solo-paisagem no Quadrilátero Ferrífero em Minas Gerais. Pesquisa Agropecuária Brasileira, 45(8):903916, 2010. 
FERNANDES, R. A. et al. Occurrence and species richness of mycorrhizal fungi in soil under different land use. Canadian Journal of Soil Science, 96(3):271-280, 2016.

FERREIRA, D. A.; CARNEIRO, M. A. C.; SAGGIN, O. J. Fungos micorrízicos arbusculares em um latossolo vermelho sob manejos e usos no Cerrado. Revista Brasileira de Ciência do Solo, 36(1):51-61, 2012.

GAZEY, C.; ABBOTT, L. K.; ROBSON, A. D. The rate of development of mycorrhizas affects the onset of sporulation and production of external hyphae by two species of Acaulospora. Mycological Research, 96(8):643-650, 1992.

GERDEMANN, J. W.; NICOLSON, T. H. Spores of mycorrhizal endogone species extracted from soil by wet sieving and decanting. Transactions of the British Mycological Society, 46(2):235-244, 1963.

GIOVANNETTI, M.; MOSSE, B. An evaluation of techniques for measuring vesicular arbuscular mycorrhizal infection in roots. The New Phytologist, 84:489-500, 1980.

GOTO, B. T. Laboratório de Biologia de Micorrizas Universidade Federal do Rio Grande do Norte. 2016. Available in: <http://glomeromycota.wixsite.com/ Ibmicorrizas/cpia>. Access in: April, 10, 2017.

HAMMER, $\varnothing$.; HARPER, D. A. T.; RYAN, P. D. PAST: Paleontological statistics software package for education and data analysis. Palaeontologia Electronica 4, 2001. Available in: <http://palaeo-electronica.org/2001_1/past/issue1_01. htm>. Access in: Oct. 26, 2015

HOPPER, S. D.; SILVEIRA, F. A. O.; FIEDLER, P. L. Biodiversity hotspots and Ocbil theory. Plant and Soil, 403(1-2):167216, 2016

HUISING, E. J. et al. Estratégia e modelo de amostragem para avaliar a biodiversidade do solo. In: MOREIRA, F. M. S.; HUISING, E. J.; BIGNELL, D. E. (Eds.) Manual de biologia dos solos tropicais: Amostragem e caracterização da biodiversidade. Lavras: Editora UFLA, 2008. p.43-78.

INVAM International Culture Collection of (Vesicular) Arbuscular Mycorrhizal Fungi. West Virginia University. 2016. Available in: <http://invam.wvu.edu/>. Access in: September, 25, 2016.

JENKINS, W. R. A rapid centrifugal-flotation technique for separating nematodes from soil. Plant Disease Reporter, 48:692, 1964.

JUGE, C. et al. Breaking dormancy in spores of the arbuscular mycorrhizal fungus Glomus intraradices: A critical coldstorage period. Mycorrhiza, 12(1):37-42, 2002.
KIERNAN, J. M.; HENDRIX, J. W.; MARONEK, D. M. Endomycorrhizal fungi occurring on orphan strip mines in Kentucky. Canadian Journal of Botany, 61(6):17981803, 1983.

KLAUBER-FILHO, O.; SIQUEIRA, J. O.; MOREIRA, F. M. de S. Fungos micorrízicos arbusculares em solos de área poluída com metais pesados. Revista Brasileira de Ciência do Solo, 26(1):125-134, 2002.

KOSKE, R. E.; GEMMA, J. N. A modified procedure for staining roots to detect VA mycorrhizas. Mycological Research, 92(4):486-488, 1989.

LEIFHEIT, E. F.; VERBRUGGEN, E.; RILLIG, M. C. Arbuscular mycorrhizal fungi reduce decomposition of woody plant litter while increasing soil aggregation. Soil Biology and Biochemistry, 81:323-328, 2015.

LIANG, M. et al. Arbuscular mycorrhizal fungi counteract the Janzen-Connell effect of soil pathogens. Ecology, 96(2):562574, 2015.

LINS, C. E. L. et al. Growth of mycorrhized seedlings of Leucaena leucocephala (Lam.) de Wit. in a copper contaminated soil. Applied Soil Ecology, 31:181-185, 2006.

MATIAS, S. R. et al. Effect of rhizobia, mycorrhizal fungi and phosphate-solubilizing microorganisms in the rhizosphere of native plants used to recover an iron ore area in Brazil. European Journal of Soil Biology, 45:259-266, 2009.

MELLONI, R.; SIQUEIRA, J. O.; MOREIRA, F. M. S. Fungos micorrízicos arbusculares em solos de área de mineração de bauxita em reabilitação. Pesquisa Agropecuária Brasileira, 38(2):267-276, 2003.

MERGULHÃO, A. C. do E. S. et al. Diversity of arbuscular mycorrhizal fungi in a gypsum mining impacted semiarid area. Acta Botanica Brasilica, 24(4):10521061, 2010.

MORI, A. S.; FURUKAWA, T.; SASAKI, T. Response diversity determines the resilience of ecosystems to environmental change. Biological Reviews, 88(2):349-364, 2013.

MORTON, J. B.; BENTIVENGA, S. P.; BEVER, J. D. Discovery, measurement, and interpretation of diversity in arbuscular endomycorrhizal fungi (Glomales, Zygomycetes). Canadian Journal of Botany, 73(S1):25-32, 1995.

PAGANO, M. C. et al. Advances in Arbuscular Mycorrhizal Taxonomy. In: PAGANO, M. C. (Ed.) Recent Advances on Mycorrhizal Fungi. Cham: Springer International Publishing, 2016. p.15-21. 
PELLEGRINO, E.; BEDINI, S. Enhancing ecosystem services in sustainable agriculture: Biofertilization and biofortification of chickpea (Cicer arietinum L.) by arbuscular mycorrhizal fungi. Soil Biology and Biochemistry, 68:429-439, 2014.

RAMAN, N. et al. Mycorrhizal status of plant species colonizing a magnesite mine spoil in India. Biology and Fertility of Soils, 16:76-78, 1993.

RANGEL, W. D. M. et al. Phytoprotective effect of arbuscular mycorrhizal fungi species against arsenic toxicity in tropical leguminous species. International Journal of Phytoremediation, 16(7-8):840-858, 2014.

ROCHA, M. R. da; OLIVEIRA, E. de; CARVALHO, G. de. Efeitos de doses de fósforo e fungos MVA no crescimento e nutrição mineral da tangerineira "Cleopatra" (Citrus reshivi Hort ex Tan) em sementeira. Pesquisa Agropecuária Brasileira, 29(5):725-731, 1994.

ROSENDAHL, S. Communities, populations and individuals of arbuscular mycorrhizal fungi. New Phytologist, 178(2):253266, 2008.

SANTOS, A. L. dos et al. Estabelecimento e capacidade infectiva de Gigaspora margarita e Glomus clarum em solo sob erosão. Acta Botanica Brasilica, 14(11):127139, 2000.

SILVA, E. et al. Variation of arbuscular mycorrhizal fungal communities along an altitudinal gradient in rupestrian grasslands in Brazil. Mycorrhiza, 25:627-638, 2015.

SILVA, F. de A. S. E; AZEVEDO, C. A. V. de. The Assistat Software Version 7.7 and its use in the analysis of experimental data. African Journal of Agricultural Research, 11(39):37333740, 2016.

SIQUEIRA, J. O. et al. Micorrizas e a degradação do solo: Caracterização, efeitos e ação recuperadora. In: CERETTA, C. S.; SILVA, L. S.; REICHERT, J. M. (Eds.) Tópicos em Ciência do Solo. Viçosa, MG: Sociedade Brasileira de Ciência do Solo, 2007. p.219-306.

SIQUEIRA, J. O.; COLOZZI-FILHO, A.; OLIVEIRA, E. D. E. Ocorrência de micorrizas vesicular-arbusculares em agro e ecossistemas do estado de Minas Gerais. Pesquisa Agropecuária Brasileira, 24(12):1499-1, 1989.

SKIRYCZ, A. et al. Canga biodiversity, a matter of mining. Frontiers in Plant Science, 5(653):1-9, 2014.
SOARES, C. R. F. S.; CARNEIRO, M. A. C. Micorrizas arbusculares na recuperação de áreas degradadas. In: SIQUEIRA, J. O. (Ed.) Micorrizas: $\mathbf{3 0}$ anos de pesquisa no Brasil. Lavras: Editora UFLA, 2010. p.441-474.

STÜRMER, S. L.; SIQUEIRA, J. O. Diversidade de fungos micorrízicos arbusculares em ecossistemas brasileiros. In: MOREIRA, F. M. DE S.; SIQUEIRA, J. O.; BRUSSAARD, L. (Eds.) Biodiversidade do solo em ecossistemas brasileiros. Lavras: Editora UFLA, 2008. p.537-584.

STUTZ, J. C.; MORTON, J. B. Successive pot cultures reveal high species richness of arbuscular endomycorrhizal fungi in arid ecosystems. Canadian Journal of Botany, 74(12):1883-1889, 1996.

TER BRAAK, C.; SMILAUER, P. Canoco Reference Manual and User's Guide to Canoco for Windows: Software for Canonical Community Ordination (version 4). Ithaca, USA: Microcomputer Power, 1998. 352p.

THIRKELL, T. J.; CAMERON, D. D.; HODGE, A. Resolving the "nitrogen paradox" of arbuscular mycorrhizas: Fertilization with organic matter brings considerable benefits for plant nutrition and growth. Plant, Cell \& Environment, 39(8):1683-1690, 2016.

THOMÉ, V. M. R. et al. Zoneamento agroecológico e socioeconômico do estado de Santa Catarina. Florianópolis: Epagri, 1999. 1010p.

TREJO, D.; BAROIS, I.; SANGABRIEL-CONDE, W. Disturbance and land use effect on functional diversity of the arbuscular mycorrhizal fungi. Agroforestry Systems, 90(2):265-279, 2016.

VAN DER HEIJDEN, M. G. A. et al. Mycorrhizal fungal diversity determines plant biodiversity, ecosystem variability and productivity. Nature, 396(6706):69-72, 1998.

VAN DER HEYDE, M. et al. Arbuscular mycorrhizal fungus responses to disturbance are context-dependent. Mycorrhiza, 1-10, 2016.

XING, Y. et al. Multiple factors affect diversity and abundance of ammonia-oxidizing microorganisms in iron mine soil. Archives of Environmental Contamination and Toxicology, 69(1):20-31, 2015.

ZHANG, Y.; GUO, L.-D.; LIU, R.-J. Survey of arbuscular mycorrhizal fungi in deforested and natural forest land in the subtropical region of Dujiangyan, southwest China. Plant and Soil, 261(1/2):257-263, 2004. 